\title{
On the Hybrid Nature of REITs
}

\author{
Walter I. Boudry \& N. Edward Coulson \& \\ Jarl G. Kallberg \& Crocker H. Liu
}

The consensus that emerges from the current research on the linkage between securitized and direct investment in real estate is that direct (private) real estate returns play a relatively minor role in the real estate investment trust (REIT) return generating process. However, this result may at least partially be due to the coarseness of the measures of direct real estate returns or the relatively short return horizons used in previous studies. This study takes a different and unique perspective. Unlike earlier studies we do not use aggregated, average appraisal based returns on direct real estate investment. Instead, we use the MIT TBI indexes, which are transaction based price indexes, available both on the aggregate and subindex levels. We find that the relation between REIT and direct real estate returns appears to be stronger at longer horizons. More specifically, using a cointegration framework, we find robust evidence that REITS and the underlying real estate are related and that they share a long run equilibrium. Interestingly, we find that both REITs and direct real estate returns adjust towards this long run relationship. When we examine property type level data we find similar results.

\section{Introduction}

Recent empirical evidence (surveyed briefly in "Literature Review") has provided increasing support for the unsettling notion that the prices of publicly traded equities are drifting further from their underlying fundamentals (such as innovations in earnings, project returns, costs of capital, etc.). These findings, of course, have very profound implications for the rationality and efficiency of modern financial markets, and add to the concern financial economists have about our ability to reasonably explain fluctuations in asset prices. As noted in Shiller (1989):

The origins of price movements are poorly known in all speculative markets: markets for corporate stocks, bonds, homes, land, commercial structures, commodities, collectibles, and foreign exchange. 
It is significant that real estate is prominently featured in this quote as the price dynamics of securitized real estate investment trusts (REITs) are the focus of this study. This topic has received a great deal of attention in the academic and practitioner literature. In particular, the extent to which REIT returns are related to returns in the underlying "real" markets has been the focus of a significant amount of research and naturally is of very great practical significance. The following quotes from three practitioners illustrate various viewpoints on this issue ${ }^{1}$ :

- REITs are real estate that happens to perform like stock. The underlying asset is the same, it's just that the wrapper is different. And depending on which wrapper you put around the real estate the real estate will perform differently. ${ }^{2}$

- The longer a REIT is in existence the more it becomes like a stock company. ${ }^{3}$

- REITs behave like stocks over the short term, but they should reflect the underlying real estate values over the long term. ${ }^{4}$

In light of the recent mortgage crisis, it would seem logical to believe that the direct real estate markets have a profound influence on financial assets. However, while there is no true consensus in the extant academic literature, a number of studies have suggested that direct real estate returns play a relatively minor role in the REIT return generating process. $^{5}$

We expand on the existing research in three directions. First, we use transactions based private real estate returns. Due to data limitations, prior studies have relied almost exclusively on appraisal based measures of private real estate returns. Since we are interested in the statistical relation between time series, having measures of returns that do not inherently have biased means, variances and correlations is critical. Second, most studies have focused on aggregate REIT returns. While we examine aggregate REIT returns, we also examine pricing at the property type level. Since the fundamental drivers of growth may differ between property types, it is logical that return dynamics may differ at the property type level as well. Finally, we examine these structural relations at varying and longer time horizons.

Our examination of simple correlations shows that the correlation between REITs and real estate increases over the return horizon. That is, REITs and real estate appear to be more strongly correlated at longer horizons. Given that the relation between REITs and real estate may be a long run

\footnotetext{
${ }^{1}$ These are taken from: National Real Estate Investors, Hey investor! Are REITs stock or real estate? Oct 1, 1995.

${ }^{2}$ Russell Platt (Morgan Stanley Asset Management).

${ }^{3}$ Mark Brumbaugh (Coopers \& Lybrand).

${ }^{4}$ Richard Schoninger (Prudential Securities).

${ }^{5}$ See, i.a., Giliberto (1990), Seck (1996), Zeiring et al. (1997), Clayton and MacKinnon (2003) and Ling and Naranjo (2003).
} 
phenomenon, we employ a vector error correction model to examine a possible cointegrating relation between the two.

Using this cointegration framework, we find robust evidence that the returns on REITs and the underlying real estate are related. At the aggregate level we find that REITs and real estate are cointegrated, which indicates that they share a long run equilibrium. Interestingly, we find that both REITs and real estate adjust towards this long run relation.

When we examine property type level data we find similar results. Except for the office market, REITs and real estate appear to be part of the same cointegrating relation. Once again, both markets appear to adjust towards this long run equilibrium.

The remainder of this paper is organized as follows. "Literature Review" presents a brief overview of the relevant academic literature. "Data" describes the data and "Empirical Strategy" outlines our econometric approach. "Results" summarizes our empirical analysis and "Conclusions" concludes.

\section{Literature Review}

This study is part of a growing literature that questions the extent to which fundamental factors influence the stochastic process governing the returns on publicly traded assets. This issue was initially framed in terms of the levels and dynamics of asset volatility. The early work of Shiller (1981), LeRoy and Porter (1981), West (1988) and Campbell and Shiller (1988) showed that, for common equity indexes, stock price variability was much higher than the variability associated with fundamentals and that the basic present value relation was not supported by equity index return data. ${ }^{6}$

However, Kallberg et al. (2003) show that the dividend pricing models tested by West and Campbell and Shiller cannot be rejected for REITs, reinforcing the important role of dividends as a REIT pricing factor.

A recent branch of this literature has focused on estimating $A R C H$ and related stochastic volatility models, typically analyzing the dynamics of the volatility of stock prices over time. An example is Campbell et al. (2001), which shows that, while the volatility of stock indexes has not appreciably increased from 1962 to 1997, the volatility of individual firms has nearly doubled over this period. They further show that increased volatility levels can forecast macroeconomic variables.

\footnotetext{
${ }^{6}$ However, Ackert and Smith (1993) show that including share repurchase and other distributions leads to a failure to reject the dividend pricing model.
} 
This divergence between prices and the dynamics governing fundamentals is particularly relevant to real estate securities. While securitized real estate assets such as REITs were originally believed to be a more liquid alternative to direct real estate investment, recent evidence increasingly, but not universally, supports the idea that the statistical links between REIT returns and the performance of the underlying real asset markets are weak. This observation was originally made in Seck (1996) and Seiler et al. (2001). Furthermore, Zeiring et al. (1997) and Clayton and Mackinnon (2003) show that, in the post-1992 era, REITs behaved less like equity and more like the underlying real estate. However, the power of their return generating process falls over their sample period. More recently, Mulhofer (2011) attributes the lack of a linkage between "real" real estate and securitized real estate to the fact that the capital appreciation component of returns is largely missing from REITs.

Two papers very relevant to this study are Clayton and MacKinnon (2003) and Ling and Naranjo (2003). Clayton and Mackinnon assume a return generating process containing a stock index return (S\&P500 and Russell 2000), a bond index (Lehman Brothers indexes of returns on long-term corporate and government bonds), and an index of returns on direct real estate investment (a modification of the NCREIF total return index as noted earlier). After orthogonalizing these factors to create a purer bond and real estate factor, they decompose the total volatility. They find that for the time period 1979 to 1984, REIT volatility is highly related to equities, with very little correlation with the underlying real estate returns. In contrast, over the period 1992-1998, they find that the real estate factor becomes more important, although the overall model fit is much worse in this period. ${ }^{7}$

They posit that real estate cycles and the presence of institutional investors can explain these differences. Ling and Naranjo (2003) explore the latter issue, focusing on the lead-lag relation between investment flows into REITs and REIT index returns. Using a vector autoregression approach, they find evidence of return chasing behavior (positive momentum), but find no consistent evidence that REIT equity flows influence future REIT returns.

The most recent approach to this research question has been through estimating the degree of cointegration. Tuluca et al. (2000) estimate the cointegration among real estate markets (public and private), T-bills, bonds and stocks. They find evidence of feedback between public and private markets and suggest that, in the short run, private real estate markets can actually informationally lead public REIT markets. Anderson et al. (2009) find similar results after correcting for the interaction of real estate markets with the stock and bond markets. They further show that the equity market has become part of

\footnotetext{
${ }^{7}$ The idiosyncratic component of their model is $13.7 \%$ over 1979 to 1984 , but rises to $62.5 \%$ over 1992 to 1998 . This is important since Ooi et al. (2009) demonstrate that REIT idiosyncratic risk is positively correlated with returns.
} 
the cointegrated relation and that the private market has recently exhibited greater informational efficiency. $^{8}$

\section{Data}

The standard approach adopted to examine REIT returns is to consider them as spanned by some combination of real estate, stock and bond factors. While there is no consensus as to exactly what these reference assets should be, based on previous research we use four candidates: (1) the MIT NCREIF transactions based index; (2) the S\&P 500; (3) the Russell 2000 value index; and (4) the Barclay's BAA long term bond index.

Since the return dynamics of REITs may differ by property type, we examine five different sets of REIT returns. To capture aggregate REIT dynamics, we employ the FTSE NAREIT equity REIT index. To examine property type level effects, we examine the FTSE NAREIT property type indexes (office, retail, industrial and apartment). Data are obtained from NAREIT's webpage.

Since a key relation of interest in this study is the linkage between securitized real estate (REITs) and unsecuritized real estate, the careful choice of an appropriate underlying real estate index is necessary. This choice of index is influenced by issues related to both index construction and asset matching.

The choice of index construction comes down to a selection between appraisal based indexes and transactions based indexes. Prior studies have almost exclusively used appraisal based indexes. While the severe disadvantages of these appraisal based indexes are well known, ${ }^{9}$ they were until recently the only indexes available. However, several transactions based indexes have been developed in the past few years. While still in their infancy, these transactions based indexes do not appear to suffer from several of the problems that arise in the appraisal based indexes. As such, it is logical to employ a transactions based index over an appraisal based index.

The second issue in index selection is asset matching. While the mechanical process of constructing a return index using transactions rather than appraisals is appealing, improving the mechanics only matters if the underlying properties that go into creating the index are a good match to the securitized real estate we are analyzing. Since REITs tend to invest in institutional quality real estate, an ideal index would be constructed based on a similar set of properties. In this regard, the NCREIF

\footnotetext{
${ }^{8}$ A contrasting view is presented in Chiang (2009), which shows that past returns on public markets can forecast returns in real markets. This result is consistent with the notion that public markets are more efficient in processing information than private markets.

${ }^{9}$ See Geltner et al. (2007) for a textbook discussion.
} 
universe of properties would make an excellent match to the set of REIT properties, since both groups tend to invest in institutional quality real estate.

Taking these two arguments into consideration, the real estate indexes we employ are the NCREIF MIT TBI developed by Fisher et al. (2007). These series are based on transactions prices drawn from the universe of NCREIF properties. The fact that these indexes are transaction rather than appraisal based, and also are formed from transactions in the NCREIF universe, suggest they are the best available series from both a construction and asset matching perspective.

The major limitation in using the MIT TBI is data availability. Unlike appraisal based series that are available back into the 1970s, the TBI are available only from Q2 1984 at the aggregate level and Q2 1994 at the property type level. While this lack of data may appear to be a significant disadvantage, studies have suggested that the REIT return generating process may have changed through time. Two commonly suggested events for changes are the start of the new REIT era in the early 1990s and the relaxation of the $5 / 50$ rule in $1993 .{ }^{10}$ Since data availability constrains our analysis at the property type level to 1994 onwards, we are essentially examining the era of most relevance: the new REIT era.

As discussed above, the relation between REITs and equity returns has been well documented in the literature. Since REITs are traded equities, it is logical to expect some relation to the overall equity markets. To proxy for this effect, we employ the S\&P500 index. Notice however that the S\&P500 proxies for the large cap universe of stocks, which may not be representative of the REIT universe. If one expects fundamental differences in return dynamics based on market cap or growth, the S\&P 500 may not be the appropriate equity index since REITs tend to be small/mid cap value stocks. ${ }^{11}$ To capture this possible small/mid cap value effect, we also include the Russell 2000 value index. We obtain the S\&P 500 from CRSP and the Russell 2000 value index from Global Insight.

The steady cash flows produced by commercial real estate combined with the dividend payout requirements imposed on REITs means that REITs have large and fairly steady dividend payouts. ${ }^{12}$ Viewed in this way, REITs may be viewed as a bond substitute to investors and thus trade in a similar way to corporate bonds. To capture this possibility, we incorporate the Barclay's BAA long-term bond index. We obtain these data from Datastream.

\footnotetext{
${ }^{10}$ See Glascock et al. (2000) and Morawski et al. (2008).

${ }^{11}$ See Liu and Mei (1992) and Chiang and Lee (2002).

${ }^{12}$ See Boudry (2011) and Hardin and Hill (2008) for a discussion of REIT dividend policy.
} 


\section{Descriptive Statistics}

Table 1 reports descriptive statistics for the data used in our analysis. Panel A reports quarterly returns for the FTSE NAREIT equity REIT index (REIT), the aggregate NCREIF MIT TBI (RE), the S\&P 500, Russell 2000 value index and the Barclay's BAA long-term bond index. These data cover the period Q2 1984 to Q4 2009. Panel B reports returns over the sub-sample Q2 1994 to Q4 2009 for which property type level returns are available.

The returns in Table 1 reveal some important facts. First, the comparison between REIT and RE shows that the RE is much less volatile than the REIT. The full sample REIT standard deviation is 0.10 compared to 0.044 for RE. Over the short sample, the average standard deviation of the four REIT types is 0.1335 compared to an average of 0.048 for RE. Note that this is not an artifact of appraisal smoothing commonly found in the prior literature, since the RE are transactions based. Second, Panel B shows that there is significant variation among property types in both the REIT and RE markets. For example, the standard deviations range from 0.114 to 0.154 for the four REIT sub-indexes. This suggests that the dynamics observed at the aggregate level may not hold uniformly for each property type. Finally, the large minimum and maximum quarterly observations imply that the sample period includes both bull and bear markets, so our analysis is not driven by sampling over just one segment of the real estate cycle.

To examine the relation between REITs and the other return series, a natural first step is to calculate pair-wise correlations. Since it has been argued that REITs behave more like real estate over longer horizons, we calculate correlations at the quarterly, annual and 3-year level. For both the annual and 3-year returns, we calculate returns over non-overlapping periods starting with the first available observation.

Table 2 reports pair-wise correlations over the full sample period, while Table 3 reports correlations over the shorter Q2 1994 to Q4 2009 time period for which property type data is available. In each case Panel A reports quarterly returns, Panel B reports annual returns and Panel C reports 3-year returns. Notice that the use of non-overlapping returns means that as the frequency of the returns decreases so does the sample size. 
Table 1 Descriptive statistics

\begin{tabular}{|c|c|c|c|c|c|}
\hline Index & Obs & Mean & Stdev & Min & $\operatorname{Max}$ \\
\hline \multicolumn{6}{|c|}{ Panel A: Full Sample (Q2 1984 to Q4 2009) } \\
\hline REIT & 103 & 0.007 & 0.100 & -0.511 & 0.277 \\
\hline $\mathrm{RE}$ & 103 & 0.003 & 0.044 & -0.198 & 0.164 \\
\hline S\&P500 & 103 & 0.019 & 0.084 & -0.264 & 0.190 \\
\hline Russell 2000 & 103 & 0.020 & 0.100 & -0.325 & 0.247 \\
\hline Bond & 103 & 0.003 & 0.051 & -0.222 & 0.152 \\
\hline \multicolumn{6}{|c|}{ Panel B: Short Sample (Q2 1994 to Q4 2009) } \\
\hline REIT & 63 & 0.006 & 0.116 & -0.511 & 0.277 \\
\hline REIT (Office) & 63 & 0.013 & 0.126 & -0.528 & 0.363 \\
\hline REIT (Retail) & 63 & 0.007 & 0.137 & -0.643 & 0.314 \\
\hline REIT (Industrial) & 63 & 0.003 & 0.157 & -0.860 & 0.280 \\
\hline REIT (Apartment) & 63 & 0.009 & 0.114 & -0.474 & 0.307 \\
\hline $\mathrm{RE}$ & 63 & 0.008 & 0.047 & -0.198 & 0.164 \\
\hline RE (Office) & 63 & 0.009 & 0.046 & -0.126 & 0.093 \\
\hline RE (Retail) & 63 & 0.007 & 0.045 & -0.103 & 0.207 \\
\hline RE (Industrial) & 63 & 0.008 & 0.056 & -0.230 & 0.219 \\
\hline RE (Apartment) & 63 & 0.011 & 0.045 & -0.141 & 0.164 \\
\hline S\&P500 & 63 & 0.015 & 0.087 & -0.256 & 0.190 \\
\hline Russell 2000 & 63 & 0.017 & 0.099 & -0.294 & 0.200 \\
\hline Bond & 63 & -0.001 & 0.057 & -0.222 & 0.152 \\
\hline
\end{tabular}

Table reports descriptive statistics for the data used in the analysis. Panel A reports statistics for the full sample, Q2 1984 to Q4 2009, while Panel B reports statistics for the Q2 1994 to Q4 2009 sample. REIT is the NAREIT FTSE Equity REIT Index, while REIT (Office, Retail, Industrial and Apartment) are the NAREIT FTSE Equity REIT property type indexes. RE is are aggregate MIT TBI, while RE(Office, Retail, Industrial and Apartment) are the MIT TBI property type indexes. S\&P500 is the S\&P 500 index, Russell 2000 is the Russell 2000 value index and Bond is the Barclay's BAA long term corporate bond index. All data are quarterly

If REITs do in fact behave more like real estate at longer horizons, we would expect to see the correlations between REIT and RE increase as we move from quarterly to annual and 3-year returns. This appears to be the case in Table 2. At the aggregate level, the correlation between REIT and RE increases from 0.21 at the quarterly level to 0.61 at the annual level. The correlation falls to 0.40 at the 3 -year level, but some caution may be required in interpreting this point estimate since the 3-year return correlations are based on only three observations. Nonetheless, the data appear to be supportive of the notion that in aggregate REITs behave more like real estate at longer horizons. Consistent with the findings in Table 2, Table 3 shows that this result also holds at the property type level. Once again REIT returns are more highly correlated with direct real estate returns at longer horizons. The average 
correlation of RE with the four REIT sub-indexes rises from 0.28 to 0.75 as we move from quarterly to annual returns.

Table 2 Correlations: full sample

\begin{tabular}{|c|c|c|c|c|c|}
\hline & REIT & $\mathrm{RE}$ & S\&P500 & Russell 2000 & Bond \\
\hline \multicolumn{6}{|c|}{ Panel A: Full Sample Quarterly Returns (103 obs) } \\
\hline REIT & 1.00 & 0.21 & 0.59 & 0.78 & 0.30 \\
\hline $\mathrm{RE}$ & 0.21 & 1.00 & 0.21 & 0.22 & 0.14 \\
\hline S\&P500 & 0.59 & 0.21 & 1.00 & 0.81 & 0.26 \\
\hline Russell 2000 & 0.78 & 0.22 & 0.81 & 1.00 & 0.26 \\
\hline Bond & 0.30 & 0.14 & 0.26 & 0.26 & 1.00 \\
\hline \multicolumn{6}{|c|}{ Panel B: Full Sample Annual Returns (25 obs) } \\
\hline REIT & 1.00 & 0.61 & 0.64 & 0.88 & 0.51 \\
\hline $\mathrm{RE}$ & 0.61 & 1.00 & 0.42 & 0.45 & 0.21 \\
\hline S\&P500 & 0.64 & 0.42 & 1.00 & 0.73 & 0.39 \\
\hline Russell 2000 & 0.88 & 0.45 & 0.73 & 1.00 & 0.54 \\
\hline Bond & 0.51 & 0.21 & 0.39 & 0.54 & 1.00 \\
\hline \multicolumn{6}{|c|}{ Panel C: Full Sample 3-year Returns (8 obs) } \\
\hline REIT & 1.00 & 0.40 & 0.08 & 0.79 & 0.47 \\
\hline RE & 0.40 & 1.00 & 0.24 & -0.01 & -0.21 \\
\hline S\&P500 & 0.08 & 0.24 & 1.00 & 0.14 & 0.52 \\
\hline Russell 2000 & 0.79 & -0.01 & 0.14 & 1.00 & 0.73 \\
\hline Bond & 0.47 & -0.21 & 0.52 & 0.73 & 1.00 \\
\hline
\end{tabular}

Table reports correlations for the data used in the analysis. REIT is the NAREIT FTSE Equity REIT Index and RE is the aggregate MIT TBI. S\&P500 is the S\&P 500 index, Russell 2000 is the Russell 20000 value index and Bond is the Barclay's BAA long term bond index. Panel A reports uses quarterly observations from Q2 1984 to Q4 2009. Panel B uses non-overlapping annual data over Q2 1984 to Q4 2009. Panel C uses non-overlapping 3-year data for the period Q2 1984 to Q4 2009

If REITs behave more like real estate at long horizons, does that mean they behave less like financial assets? The analysis of the correlation between REITs and the equity and bond series yields mixed results. While Bond appears to be more highly correlated with REIT at longer horizons, the Russell 2000 appears to have modest increases and the correlation with the S\&P 500 might even decrease at long horizons. The differing relation between the Russell 2000 and the S\&P 500 indicates that studies employing the S\&P500 as the aggregate equity factor may miss part of the small cap equity nature of REITs.

Taken together, the results of Tables 2 and 3 suggest that any estimation technique used to examine the dynamics of REIT returns must include some long run component. Simply examining short run dynamics may mask the true relation between REITs and real estate. 
Table 3 Correlations: short sample

\begin{tabular}{|c|c|c|c|c|c|}
\hline & REIT & REIT (Office) & REIT (Retail) & REIT (Industrial) & REIT (Apartment) \\
\hline \multicolumn{6}{|c|}{ Panel A: Short Sample Quarterly Returns (63 obs) } \\
\hline RE & 0.27 & 0.28 & 0.24 & 0.29 & 0.31 \\
\hline RE (Office) & 0.15 & 0.14 & 0.14 & 0.20 & 0.14 \\
\hline RE (Retail) & 0.11 & 0.10 & 0.13 & 0.12 & 0.08 \\
\hline RE (Industrial) & 0.48 & 0.45 & 0.47 & 0.47 & 0.52 \\
\hline RE (Apartment) & 0.27 & 0.27 & 0.26 & 0.39 & 0.29 \\
\hline S\&P500 & 0.58 & 0.63 & 0.51 & 0.56 & 0.53 \\
\hline Russell 2000 & 0.81 & 0.80 & 0.73 & 0.67 & 0.76 \\
\hline Bond & 0.32 & 0.37 & 0.33 & 0.32 & 0.26 \\
\hline \multicolumn{6}{|c|}{ Panel B: Short Sample Annual Returns ( $15 \mathrm{obs})$} \\
\hline RE & 0.74 & 0.72 & 0.75 & 0.75 & 0.78 \\
\hline RE (Office) & 0.72 & 0.73 & 0.68 & 0.71 & 0.76 \\
\hline RE (Retail) & 0.45 & 0.38 & 0.52 & 0.44 & 0.44 \\
\hline RE (Industrial) & 0.84 & 0.82 & 0.85 & 0.88 & 0.88 \\
\hline RE (Apartment) & 0.67 & 0.67 & 0.64 & 0.72 & 0.75 \\
\hline S\&P500 & 0.65 & 0.73 & 0.59 & 0.67 & 0.65 \\
\hline Russell 2000 & 0.89 & 0.89 & 0.80 & 0.76 & 0.86 \\
\hline Bond & 0.54 & 0.53 & 0.56 & 0.48 & 0.49 \\
\hline \multicolumn{6}{|c|}{ Panel C: Short Sample 3-year Returns (4 obs) } \\
\hline RE & 0.64 & 0.46 & 0.53 & 0.60 & 0.86 \\
\hline RE (Office) & 0.50 & 0.57 & 0.25 & 0.52 & 0.74 \\
\hline RE (Retail) & 0.57 & 0.19 & 0.61 & 0.48 & 0.77 \\
\hline RE (Industrial) & 0.72 & 0.55 & 0.59 & 0.69 & 0.91 \\
\hline RE (Apartment) & 0.91 & 0.89 & 0.69 & 0.93 & 0.96 \\
\hline S\&P500 & -0.11 & 0.33 & -0.47 & -0.03 & 0.12 \\
\hline Russell 2000 & 0.82 & 0.81 & 0.59 & 0.84 & 0.94 \\
\hline Bond & 0.60 & 0.16 & 0.83 & 0.53 & 0.38 \\
\hline
\end{tabular}

Table reports correlations for the data used in the analysis. REIT is the NAREIT FTSE Equity REIT Index, while REIT (Office, Retail, Industrial and Apartment) are the NAREIT FTSE Equity REIT property type indexes. RE is are aggregate MIT TBI, while RE (Office, Retail, Industrial and Apartment) are the MIT TBI property type indexes. S\&P500 is the S\&P 500 index, Russell 2000 is the Russell 20000 value index and Bond is the Barclay's BAA long term bond index. Panel A reports uses quarterly observations from Q2 1994 to Q4 2009. Panel B uses non-overlapping annual data over Q2 1994 to Q4 2009. Panel C uses non-overlapping 3-year data for the period Q2 1994 to Q4 2009

\section{Empirical Strategy}

To examine the dynamics of REIT returns we need a methodology that allows for the hypothesized long term dynamics. The approach we adopt is to estimate a vector error correction model (VECM). The VECM can easily be derived by starting with a standard vector autoregressive process $(\mathrm{VAR})^{13}$

$$
y_{t}=v+A_{1} y_{t-1}+A_{2} y_{t-2}+\ldots+A_{p} y_{t-p}+\varepsilon_{t},
$$

\footnotetext{
${ }^{13}$ See StataCorp. (2009) for a textbook discussion.
} 
where $y_{t}$ is a $K \times 1$ vector of variables (REIT, RE, S\&P500, Russell 2000 and Bond), $v$ is a $K \times 1$ vector of parameters, $A_{1}$ to $A_{p}$ are $K \times K$ matrices of parameters, and $\varepsilon_{t}$ is a $K \times 1$ vector of i.i.d. normal error terms with mean zero and constant variance. This p-order VAR can be written in VECM form as follows:

$$
\Delta y_{t}=v+\Pi y_{t-1}+\sum_{i=1}^{p-1} \Gamma_{i} \Delta y_{t-i}+\varepsilon_{t}
$$

where $\Pi=\sum_{j=1}^{p} A_{j}-I_{k}$ and $\Gamma_{i}=-\sum_{j=1+i}^{p} A_{j} . \mathrm{v}$ and $\varepsilon_{\mathrm{t}}$ are as in above. T

VECM framework is useful in our setting because it allows for the estimation of long run cointegrating relations. Engle and Granger (1987) show that if the variables in yt are integrated of order one, then the matrix $\Pi$ in (2) must have rank $0 \leq r<K$, where $r$ is the number of linearly independent cointegrating vectors. If the variables are cointegrated, this implies that they follow a common long run stochastic trend. Since each variable is non-stationary, it can randomly deviate from the other variables in the system, but in the long run it will error correct to the cointegrating relation.

If the variables of the VECM (2) are cointegrated, then $\Pi$ can be written as the matrix product, $\alpha \beta^{\prime}$, of two Kxr matrices. $\beta$ is often referred to as the cointegrating vector, while $\alpha$ is referred to as the loading matrix. ${ }^{14}$ Decomposed in this way, $\beta$ summarizes the long run equilibrium relations, while $\alpha$ summarizes how the variables adjust to that equilibrium.

\section{Estimation}

We apply a 4-step procedure to estimate Eq. 2. First, since all variables in the system have to be of the same order of integration, we test for non-stationarity in the data (REIT, RE, S\&P 500, Russell 2000 and Bond) using Phillips Perron tests. ${ }^{15}$ Second, we estimate the optimal lag length for the system based on the VAR representation using Akaike, Schwarz's Bayesian and Hannan and Quinn information criteria. Third, we test for the number of cointegrating relations in the system using trace and maximum eigenvalue tests. Finally, we estimate (2) above imposing the number of cointegrating relations found in Step 3 and the optimal lag length found in Step 2.

Table 4 reports Phillips Perron tests for the variables used in the analysis. The test assumes a null hypothesis of non-stationarity. Thus a significant test statistic is a rejection of the null hypothesis of non-stationarity and indicates that the variable is covariance stationary. In each case we perform Phillips Perron tests first on the levels of each variable and then on the first differences. The $p$-values, reported for the test statistics based on the variables in levels, indicate that we are unable to reject the null

\footnotetext{
${ }^{14}$ See Lütkepohl (2005) for details.

${ }^{15}$ See Phillips (1987) and Phillips and Perron (1988).
} 
hypothesis of non-stationarity at conventional significance levels for all variables examined. We test whether the variables are first difference stationary by taking first differences and then repeating the Phillips Perron tests. Since the index levels are in logs, this tests whether the index returns are stationary. In this case we are able to reject the null hypothesis of non-stationarity for each variable, which implies that all variables are integrated of order one and are first difference stationary.

Table 4 Unit root tests

\begin{tabular}{|c|c|c|c|c|}
\hline \multirow[b]{2}{*}{ Variable } & \multicolumn{2}{|l|}{ Levels } & \multicolumn{2}{|c|}{ First difference } \\
\hline & $Z(\mathrm{t})$ & $P$-value & $Z(\mathrm{t})$ & $P$-value \\
\hline REIT & -2.76 & 0.21 & -8.07 & $<0.01$ \\
\hline REIT (Office) & -2.10 & 0.55 & -5.64 & $<0.01$ \\
\hline REIT (Retail) & -1.79 & 0.71 & -6.19 & $<0.01$ \\
\hline REIT (Industrial) & -1.51 & 0.83 & -5.03 & $<0.01$ \\
\hline REIT (Apartment) & -2.43 & 0.36 & -6.58 & $<0.01$ \\
\hline RE & -1.69 & 0.76 & -9.24 & $<0.01$ \\
\hline RE (Office) & -0.71 & 0.97 & -4.91 & $<0.01$ \\
\hline RE (Retail) & -1.09 & 0.93 & -6.41 & $<0.01$ \\
\hline RE (Industrial) & -0.65 & 0.98 & -7.45 & $<0.01$ \\
\hline RE (Apartment) & -0.45 & 0.99 & -6.34 & $<0.01$ \\
\hline S\&P500 & -2.93 & 0.15 & -11.43 & $<0.01$ \\
\hline Russell 2000 & -2.72 & 0.23 & -10.58 & $<0.01$ \\
\hline Bond & -1.33 & 0.88 & -9.45 & $<0.01$ \\
\hline
\end{tabular}

Table reports Phillips Perron tests on the levels and first differences of the data used in the analysis. REIT is the NAREIT FTSE Equity REIT Index, while REIT (Office, Retail, Industrial and Apartment) are the NAREIT FTSE Equity REIT property type indexes. RE is are aggregate MIT TBI, while RE (Office, Retail, Industrial and Apartment) are the MIT TBI property type indexes. S\&P500 is the S\&P 500 index, Russell 2000 is the Russell 2000 value index and Bond is the Barclay's BAA long term corporate bond index. Data cover the period Q2 1984 to Q4 2009 except for the property type data that cover the period Q2 1994 to Q4 2009.

To estimate Eq. 2, we need to select, $p$, the order of lags in the VECM. The standard approach is to examine the lag lengths based on information criteria. Table 5 reports the optimal lag lengths based on the Akaike's information criteria (AIC), the Schwarz's Bayesian information criteria (SBIC) and the Hannan and Quinn information criteria (HQIC). The VAR (1) is estimated with p equal to 0 through 4. The three information criteria figures are reported for both sample periods. REIT Full Sample refers to the aggregate REIT index from Q2 1984 to Q4 2009, while REIT Short Sample refers to the aggregate REIT index from Q2 1994 to Q4 2009. REIT (Office, Industrial, Retail and Apartment) refers to the property type level REIT indexes. In each case the VAR also includes the matching MIT TBI index, S\&P 500 index, Russell 2000 value index and Barclay's BAA bond index. As discussed by Lütkepohl (2005), the SBIC and HQIC have a theoretical advantage over the AIC, in that the AIC will tend to overstate the optimal lag length. As such, where a discrepancy between the criteria is found we rely on the SBIC and HQIC over 
the AIC. In each case, the SBIC and HQIC indicate that the optimal lag length of 1 in the VAR representation or a lag length of zero in VECM representation. Although the short lag structure differs from the prior literature, ${ }^{16}$ there is a logical explanation for this. Prior studies have used appraisal based indexes, which tend to be persistent even in returns. This persistence makes a lag structure the optimal fit for the VAR. Since we use transactions based indexes, we do not observe this artificial persistence in our data. Also, in an efficient market we do not expect to observe significant serial correlation in returns, suggesting that at least from a theoretical perspective, a very short lag structure should be expected.

Table 5 Optimal lag structure

\begin{tabular}{|c|c|c|c|c|c|c|c|}
\hline \multicolumn{4}{|c|}{ REIT Full Sample } & \multicolumn{4}{|c|}{ REIT Short Sample } \\
\hline Lag & AIC & HQIC & SBIC & Lag & AIC & HQIC & SBIC \\
\hline 0 & -3.54 & -3.49 & -3.41 & 0 & -5.43 & -5.36 & -5.25 \\
\hline 1 & -14.79 & -14.47 & -14.01 & 1 & -14.62 & -14.21 & -13.57 \\
\hline 2 & -15.04 & -14.46 & -13.61 & 2 & -14.79 & -14.04 & -12.87 \\
\hline 3 & -14.83 & -13.99 & -12.75 & 3 & -14.46 & -13.37 & -11.67 \\
\hline 4 & -14.64 & -13.54 & -11.91 & 4 & -14.34 & -12.91 & -10.68 \\
\hline \multicolumn{4}{|c|}{ REIT (Office) } & \multicolumn{4}{|c|}{ REIT (Industrial) } \\
\hline 0 & -5.14 & -5.07 & -4.96 & 0 & -4.47 & -4.41 & -4.30 \\
\hline 1 & -14.46 & -14.05 & -13.41 & 1 & -13.26 & -12.85 & -12.22 \\
\hline 2 & -14.58 & -13.83 & -12.66 & 2 & -13.39 & -12.64 & -11.47 \\
\hline 3 & -14.82 & -13.72 & -12.02 & 3 & -13.03 & -11.94 & -10.24 \\
\hline 4 & -14.63 & -13.19 & -10.96 & 4 & -12.95 & -11.51 & -9.28 \\
\hline \multicolumn{4}{|c|}{ REIT (Retail) } & \multicolumn{4}{|c|}{ REIT (Apartment) } \\
\hline 0 & -4.76 & -4.69 & -4.59 & 0 & -5.69 & -5.62 & -5.52 \\
\hline 1 & -13.95 & -13.54 & -12.90 & 1 & -14.27 & -13.86 & -13.22 \\
\hline 2 & -14.13 & -13.38 & -12.21 & 2 & -14.45 & -13.70 & -12.53 \\
\hline 3 & -13.68 & -12.58 & -10.88 & 3 & -14.25 & -13.16 & -11.46 \\
\hline 4 & -13.45 & -12.02 & -9.78 & 4 & -13.87 & -12.44 & -10.21 \\
\hline
\end{tabular}

Table reports Akaike's information criteria (AIC), Schwarz's Bayesian information criteria (SBIC) and Hannan and Quinn information criteria (HQIC) for $p$-th order VAR models. REIT is the NAREIT FTSE Equity REIT Index, while REIT (Office, Retail, Industrial and Apartment) are the NAREIT FTSE Equity REIT property type indexes. The VAR specification includes the matching real estate index, either the aggregate MIT TBI or MIT TBI property type indexes, the S\&P500 index, the Russell 2000 value index and the Barclay's BAA long term corporate bond index. Data are quarterly and cover the period Q2 1994 to Q4 2009 except for REIT Full Sample which covers the period Q2 1984 to Q4 2009. Optimal lag lengths based on each criterion are in bold

Johansen (1995) shows two maximum-likelihood test statistics for the number of cointegrating relations in a VECM. Determining the number of cointegrating vectors in a VECM involves determining the rank of $\Pi$ in (2). The trace statistic is

\footnotetext{
${ }^{16}$ See, for example, Morawski et al. (2008) and Tuluca et al. (2000).
} 


$$
-T \sum_{i=r+1}^{K} \ln \left(1-\widehat{\lambda}_{i}\right)
$$

where $T$ is the number of observations and $\hat{\lambda}_{i}$ are the estimated eigenvalues of $\Pi$. For any $r$, large values of the trace statistic suggest that the rank of $\Pi$ is larger than $r$. This leads to rejection of the null hypothesis of $r$ or fewer cointegrating relations. The maximum eigenvalue test is

$$
-T \ln \left(1-\widehat{\lambda}_{r+1}\right)
$$

where $\hat{\lambda}_{r+1}$ is the $r+1^{\text {th }}$ estimated eigenvalue of $\Pi$. The maximum eigenvalue tests the null hypothesis of $r$ cointegrating vectors against the alternative of $r+1$.

Table 6 reports trace and maximum eigenvalue tests for each VECM (Aggregate full and short samples, Office, Retail, Industrial, Apartment.) Under the trace statistic, failure to reject the null hypothesis implies $r$ or fewer cointegrating vectors. For the maximum eigenvalue test, the null hypothesis is $r$ cointegrating vectors versus the alternative of $r+1$. In this case failure to reject the null implies $r$ cointegrating relations.

For the aggregate REIT index over the full sample, both the trace and maximum eigenvalue tests indicate that there is a single cointegrating relation. For the property type indexes and the aggregate index over the short sample, the trace and maximum eigenvalue tests indicate that there are generally two cointegrating relations. ${ }^{17}$ This is consistent with the results of Tuluca et al. (2000).

\section{Results}

Table 7 reports estimates from the estimation of the VECM (2). As is usual, we use the standard decomposition $\Pi=\alpha \beta^{\prime}$. Since $\beta$ is only identified to a scalar, we normalize on the first variable in the cointegrating relation. For cases where multiple cointegrating vectors exist, Johansen (1995) shows that a restriction is required to identify the parameters in $\beta$. The restriction we impose for the two cointegrating relations case is that one relation potentially contains REIT, RE, Russell 2000 and Bond, and the other captures the relation between the financial variables and real estate (S\&P500, Russell 2000, Bond and RE). ${ }^{18}$

\footnotetext{
${ }^{17}$ For the REIT (Industrial) and REIT (Apartment) the trace and maximum eigenvalue tests contradict each other. In both cases we assume two cointegrating vectors, since the test statistic indicating a single cointegrating vector is very nearly rejected at the $5 \%$ level in the contradictory test.

${ }^{18}$ This is similar to the restriction imposed in Tuluca et al. (2000).
} 
Table 6 Cointegration tests

\begin{tabular}{|c|c|c|c|c|c|}
\hline Null & Trace & Critical value & Null & $\operatorname{Max}$ & Critical value \\
\hline \multicolumn{6}{|c|}{ REIT full sample } \\
\hline$r \leq 0$ & 87.8 & 68.5 & $r=0$ & 49.7 & 33.5 \\
\hline$r \leq 1$ & 38.2 & 47.2 & $r=1$ & 24.1 & 27.1 \\
\hline$r \leq 2$ & 14.1 & 29.7 & $r=2$ & 7.4 & 21.0 \\
\hline$r \leq 3$ & 6.8 & 15.4 & $r=3$ & 5.1 & 14.1 \\
\hline \multicolumn{6}{|c|}{ REIT short sample } \\
\hline$r \leq 0$ & 111.06 & 68.52 & $r=0$ & 46.32 & 33.46 \\
\hline$r \leq 1$ & 64.74 & 47.21 & $r=1$ & 43.87 & 27.07 \\
\hline$r \leq 2$ & 20.87 & 29.68 & $r=2$ & 14.82 & 20.97 \\
\hline$r \leq 3$ & 6.05 & 15.41 & $r=3$ & 5.08 & 14.07 \\
\hline \multicolumn{6}{|c|}{ REIT (Office) } \\
\hline$r \leq 0$ & 111.0 & 68.5 & $r=0$ & 48.2 & 33.5 \\
\hline$r \leq 1$ & 62.8 & 47.2 & $r=1$ & 45.3 & 27.1 \\
\hline$r \leq 2$ & 17.5 & 29.7 & $r=2$ & 12.7 & 21.0 \\
\hline$r \leq 3$ & 4.8 & 15.4 & $r=3$ & 4.2 & 14.1 \\
\hline \multicolumn{6}{|c|}{ REIT (Industrial) } \\
\hline$r \leq 0$ & 97.6 & 68.5 & $r=0$ & 53.9 & 33.5 \\
\hline$r \leq 1$ & 43.7 & 47.2 & $r=1$ & 31.3 & 27.1 \\
\hline$r \leq 2$ & 12.4 & 29.7 & $r=2$ & 8.1 & 21.0 \\
\hline$r \leq 3$ & 4.4 & 15.4 & $r=3$ & 3.9 & 14.1 \\
\hline \multicolumn{6}{|c|}{ REIT (Retail) } \\
\hline$r \leq 0$ & 103.8 & 68.5 & $r=0$ & 50.3 & 33.5 \\
\hline$r \leq 1$ & 53.5 & 47.2 & $r=1$ & 32.2 & 27.1 \\
\hline$r \leq 2$ & 21.3 & 29.7 & $r=2$ & 16.4 & 21.0 \\
\hline$r \leq 3$ & 4.9 & 15.4 & $r=3$ & 4.2 & 14.1 \\
\hline \multicolumn{6}{|c|}{ REIT (Apartment) } \\
\hline$r \leq 0$ & 96.2 & 68.5 & $r=0$ & 48.1 & 33.5 \\
\hline$r \leq 1$ & 48.1 & 47.2 & $r=1$ & 26.5 & 27.1 \\
\hline$r \leq 2$ & 21.5 & 29.7 & $r=2$ & 14.0 & 21.0 \\
\hline$r \leq 3$ & 7.5 & 15.4 & $r=3$ & 6.8 & 14.1 \\
\hline
\end{tabular}

Table reports Johansen's trace and maximum eigenvalue tests for VECM (2). REIT refers to the VECM with the NAREIT FTSE Equity REIT Index as the REIT retum, while REIT (Office, Retail, Industrial and Apartment) are the NAREIT FTSE Equity REIT property type indexes. The VECM specification includes the matching real estate index, either the aggregate MIT TBI or MIT TBI property type indexes, the S\&P500 index, the Russell 2000 value index and the Barclay's BAA long term corporate bond index. Data are quarterly and cover the period Q2 1994 to Q4 2009 except for REIT Full Sample which covers the period Q2 1984 to Q4 2009. Null is the null hypothesis under the tests and critical values are at the 5\% level. The number of cointegrating vectors based on each test statistic is in bold

Panel A of Table 7 reports estimation results for the full sample using the FTSE NAREIT equity REIT index as the REIT index. Examining the coefficients in $\beta$ we see that all the variables are statistically significant, indicating that they all share a long run equilibrium relation. That is, REITs are like stocks, bonds and the underlying real estate in the long run. Turning to coefficients in $\alpha$, we observe that the coefficients on REIT and RE are statistically significant. This indicates that while all the variables follow a long run relation, RE and REIT are the variables that adjust to that relation. It appears that the REIT and real estate markets adjust to each other and also to the financial markets. If securitized and 
unsecuritized real estate get out of equilibrium, both adjust back towards the equilibrium path. In this sense it appears that the financial markets informationally lead the real estate markets.

Table 7 Vector error correction models

\begin{tabular}{|c|c|c|c|c|c|c|c|c|}
\hline & \multicolumn{2}{|l|}{$\alpha_{1}$} & \multicolumn{2}{|l|}{$z$} & \multicolumn{2}{|l|}{$\beta_{1}$} & \multicolumn{2}{|l|}{$z$} \\
\hline \multicolumn{9}{|c|}{ Panel A: Aggregate (Full Sample) } \\
\hline REIT & -0.21 & & -2.38 & & 1.00 & & & \\
\hline S\&P500 & -0.11 & & -1.43 & & 0.19 & & 2.56 & \\
\hline Russell 2000 & -0.13 & & -1.48 & & -0.33 & & -3.62 & \\
\hline Bond & -0.06 & & -1.36 & & -0.52 & & -2.81 & \\
\hline RE & 0.20 & & 5.73 & & -0.64 & & -6.50 & \\
\hline \multicolumn{9}{|c|}{ Panel B: Aggregate (Short Sample) } \\
\hline & $\alpha_{1}$ & $\mathrm{z}$ & $\alpha_{2}$ & $\mathrm{z}$ & $\beta_{1}$ & $\mathrm{z}$ & $\beta_{2}$ & $\mathrm{z}$ \\
\hline REIT & -0.21 & -2.16 & -0.03 & -1.43 & 1.00 & & & \\
\hline S\&P500 & -0.20 & -2.79 & -0.02 & -1.65 & & & 1.00 & \\
\hline Russell 2000 & -0.19 & -2.27 & -0.03 & -1.50 & 1.33 & 3.16 & -5.66 & -2.66 \\
\hline Bond & 0.01 & 0.23 & -0.01 & -0.92 & -7.29 & -9.02 & 30.58 & 7.51 \\
\hline RE & 0.16 & 4.72 & 0.04 & 5.63 & -2.14 & -3.72 & 4.24 & 1.46 \\
\hline \multicolumn{9}{|c|}{ Panel C: REIT (Oflice) } \\
\hline REIT & -0.20 & -2.08 & 0.03 & 2.47 & 1.00 & & & \\
\hline S\&P500 & -0.17 & -2.64 & 0.02 & 3.33 & & & 1.00 & \\
\hline Russell 2000 & -0.11 & -1.46 & 0.02 & 1.91 & -1.60 & -2.50 & -16.51 & -2.85 \\
\hline Bond & 0.00 & 0.00 & 0.00 & -0.78 & 8.07 & 5.99 & 88.74 & 7.27 \\
\hline RE & 0.15 & 5.42 & -0.01 & -4.19 & 0.25 & 0.32 & 11.70 & 1.67 \\
\hline \multicolumn{9}{|c|}{ Panel D: REIT (Retail) } \\
\hline REIT & -0.22 & -2.41 & 0.01 & 2.86 & 1.00 & & & \\
\hline S\&P500 & -0.20 & -3.62 & 0.01 & 4.12 & & & 1.00 & \\
\hline Russell 2000 & -0.17 & -2.61 & 0.01 & 2.96 & 0.13 & 0.23 & -6.34 & -0.46 \\
\hline Bond & 0.02 & 0.60 & 0.00 & -1.39 & 5.57 & 3.94 & 218.68 & 6.20 \\
\hline RE & 0.11 & 4.10 & 0.00 & -2.82 & -1.97 & -2.58 & -9.67 & -0.51 \\
\hline \multicolumn{9}{|c|}{ Panel E: REIT (Apartment) } \\
\hline REIT & -0.18 & -2.32 & 0.00 & -0.32 & 1.00 & & & \\
\hline S\&P500 & -0.14 & -2.64 & 0.00 & 0.03 & & & 1.00 & \\
\hline Russell 2000 & -0.14 & -2.06 & 0.00 & -0.13 & 1.51 & 3.75 & -7.78 & -3.10 \\
\hline Bond & -0.02 & -0.59 & -0.01 & -2.43 & -4.51 & -6.62 & 31.62 & 7.43 \\
\hline RE & 0.09 & 3.28 & 0.02 & 4.88 & -2.48 & -4.89 & 5.98 & 1.89 \\
\hline \multicolumn{9}{|c|}{ Panel F: REIT (Industrial) } \\
\hline REIT & -0.11 & -1.60 & 0.05 & 3.13 & 1.00 & & & \\
\hline S\&P500 & -0.15 & -4.45 & 0.02 & 2.94 & & & 1.00 & \\
\hline Russell 2000 & -0.11 & -2.60 & 0.02 & 2.04 & 1.92 & 5.18 & 0.18 & 0.11 \\
\hline Bond & 0.03 & 1.09 & -0.02 & -2.77 & -3.32 & -5.52 & 15.32 & 5.59 \\
\hline RE & 0.05 & 2.19 & 0.02 & 4.58 & -3.55 & -7.12 & -2.75 & -1.21 \\
\hline
\end{tabular}

Table reports estimation results for VECM (2). We report the standard decomposition $\Pi=\alpha \beta^{\prime}$ where $\alpha$ refers to the adjustment matrix while $\beta$ is the cointegrating matrix. REIT refers to the VECM with the NAREIT FTSE Equity REIT Index as the REIT return, while REIT (Office, Retail, Industrial and Apartment) are the NAREIT FTSE Equity REIT property type indexes. The VECM specification includes the matching real estate index, either the aggregate MIT TBI or MIT TBI property type indexes, the S\&P500 index, the Russell 2000 value index and the Barclay's BAA long term corporate bond index. Data are quarterly and cover the period Q2 1994 to Q4 2009 except for REIT (Full Sample) which covers the period Q2 1984 to Q4 2009. 
Panel B of Table 7 reports estimation results for the shorter Q2 1994 to Q4 2009 sample using the FTSE NAREIT equity REIT index as the REIT index. Since the results of both the trace and maximum eigenvalue tests reported in Table 6 indicate that there are two cointegrating relations, we estimate the system with two cointegrating vectors. As discussed above, we impose the restriction that one cointegrating vector contains REIT, RE, Russell 2000 and Bond, and the other captures the relation between the financial variables and real estate (S\&P500, Russell 2000, Bond and RE). Notice that we are simply hypothesizing that these two relations exist. If this does not hold in our sample, then the variables will not be statistically significant in the cointegrating vector.

Examining $\beta_{1}$ and $\beta_{2}$ in Table 7, we observe that there does appear to be two cointegrating relations: one between REIT, RE and Bond and another between the financial variables S\&P500, Russell 2000 and Bond. The fact that RE is not significant in $\beta_{2}$, suggests that the second cointegrating relation is actually just between the financial assets. That is, the financial assets appear to have their own long run equilibrium relation. Once again, an examination of $\alpha$ implies that RE and REIT adjust to each other and to the financial variables. Thus it again appears that the financial variables have their own long run equilibrium and the securitized and unsecuritized real estate markets react to this equilibrium.

Panels $\mathrm{C}$ through $\mathrm{F}$ report our property type analysis. In these panels, REIT is the FTSE NAREIT Office, Retail, Apartment and Industrial index respectively. In each case, the matching MIT TBI property type index is used as RE; we also include the S\&P 500, Russell 2000 value index and the Barclay's long term bond index.

Taken as a whole, the property type level analysis is very consistent with the relations observed in the aggregate data over the Q2 1994 to Q4 2009 period. For all property types except office, we observe a cointegrating relation between RE and REITs. Once again suggesting in the long run that securitized and unsecuritized real estate share a long run trend. An examination of the adjustment coefficients also suggests that the two markets adjust to each other and one market isn't leading the other, at least in the long run.

Turning to the second cointegrating vector, we once again observe that there appears to be a long run relation between the financial assets. RE is not significant in $\beta_{2}$ for any of the property types. This once again indicates that the second cointegrating vector governs the relations among the financial assets. 
To examine the magnitude of the relations in Table 7, we compute impulse response functions (IRF) for all the variables in each of the VECMs estimated. ${ }^{19}$ These IRFs are reported in Figs. 1 and 2. For each figure, the labeling of the IRF is "REIT Index, Impulse variable, Response variable" so "Aggregate, BOND, R2000" implies that the VECM is estimated using the aggregate REIT index and the IRF relates an impulse in Bond and the response in the Russell 2000. In this way we can examine the long run impact of a shock in one variable on another variable.

Examining the full sample results in Fig. 1, we observe that shocks to RE affects REIT and vice versa, although the magnitude appears to be slightly larger from REIT to RE. This once again highlights that REITs and unsecuritized real estate are related. The impulse response functions also suggest that for both RE and REIT, the largest impact they have is on the other real estate market. We also observe that shocks to the equity markets (S\&P500 and Russell 2000) tend to have small impacts on the other markets.

Turning to Fig. 2 and the new REIT era sample aggregate results, we see once again that REITs and RE are related. Shocks to either market have a long term impact in the other market. Once again shocks to the equity markets tend to have small impacts on the other markets. One result that does differ from the full sample result is the bond factor. Shocks to Bond appear to have long run impacts on all the other markets. This suggests that some caution may be needed in comparing the new REIT era to other time periods.

\footnotetext{
${ }^{19}$ For brevity we include only IRFs for the Aggregate series over the full sample period and the short sample period. Property type IRFs are available on request.
} 


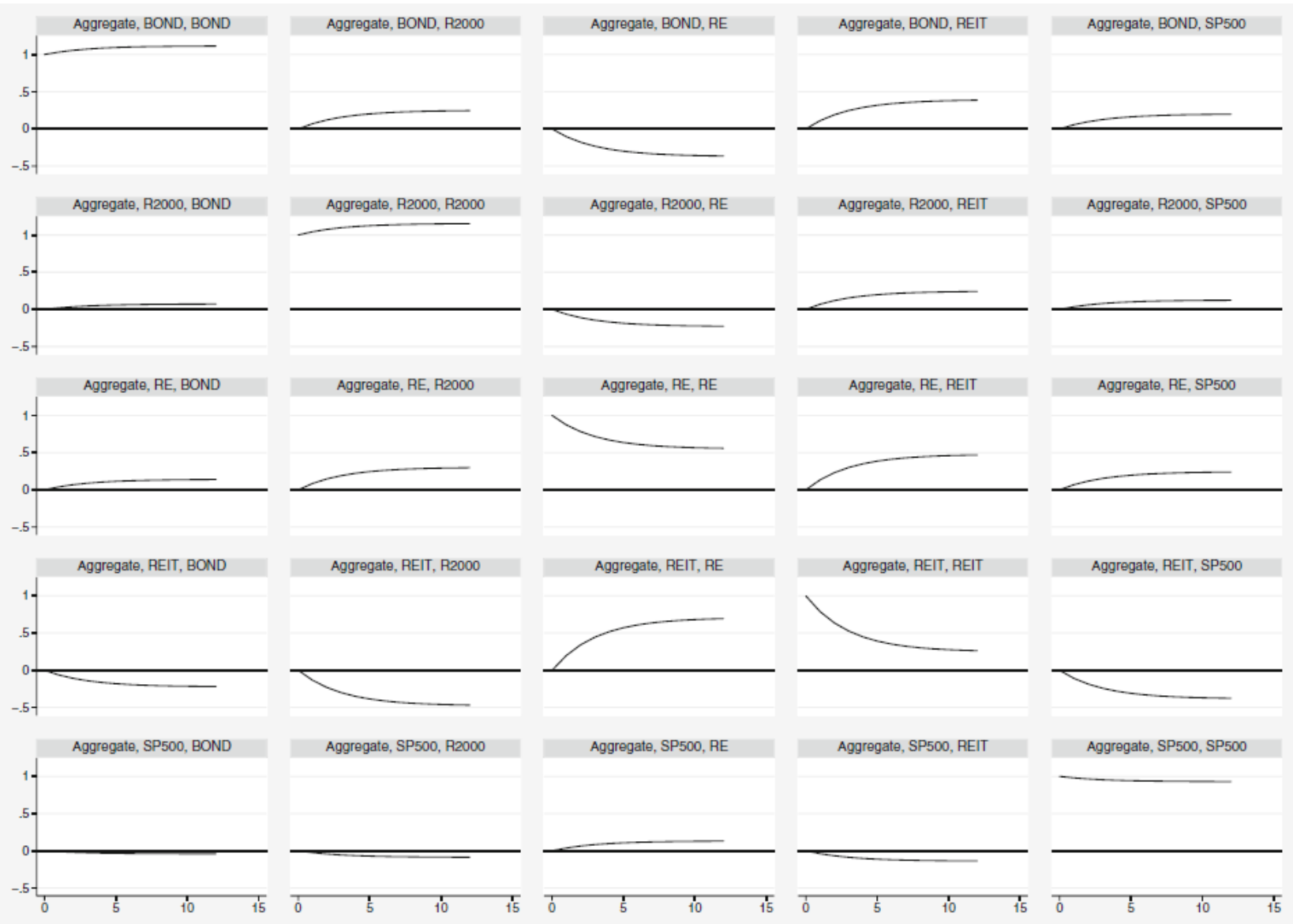

Fig. 1 Impulse Response Functions (REIT Full Sample). Figure reports impulse response functions for the VECM (2) VECM includes REIT the NAREIT FTSE Equity REIT Index, RE the aggregate MIT/TBI index, the S\&P500 index, the Russell 2000 value index and the Barclay's BAA long term corporate bond index. Data are quarterly and cover the period Q2 1984 to Q4 2009. Impulse response functions are reported for every possible impulse and response combination in the VECM and are labeled as "Aggregate, Impulse variable, Response variable"

\section{Conclusions}

This analysis has used a cointegration approach to attempt to gain further insight into the complex interactions between REIT markets and other financial markets as well as between REIT returns and the returns on direct real estate. The previous research has failed to come up with a consistent characterization of the nature of these linkages, often concluding that REIT returns have a weak relation with the returns on the underlying real assets. Part of the rationale for a lack of a previous persuasive characterization of this relation, we believe, could arise from two sources: (i) the coarseness of the measures of returns on direct real estate investment, and (ii) a focus on the short-run dynamics. 
Using transaction rather than appraisal based data we find significant evidence that REITs and the underlying real estate markets are related Furthermore, the relation appears to be stronger at longer horizons: in particular in annual rather than quarterly data. This finding holds in the aggregate as well as at the property type level.

We further observe two cointegrating relations: one between REIT, RE and Bond and another between the financial variables S\&P500, Russell 2000 and Bond. Our analysis suggests that the second cointegrating relation is actually just among the financial assets. That is, the financial assets appear to have their own long run equilibrium relation. This indicates that while all the variables follow a long run relation, RE and REIT are the variables that adjust to that relation. It appears that the REIT and real estate markets adjust to each other and also to the financial markets. If securitized and unsecuritized real estate get out of equilibrium, both adjust back towards the equilibrium path. In this sense it appears that the financial markets informationally lead the real estate markets.

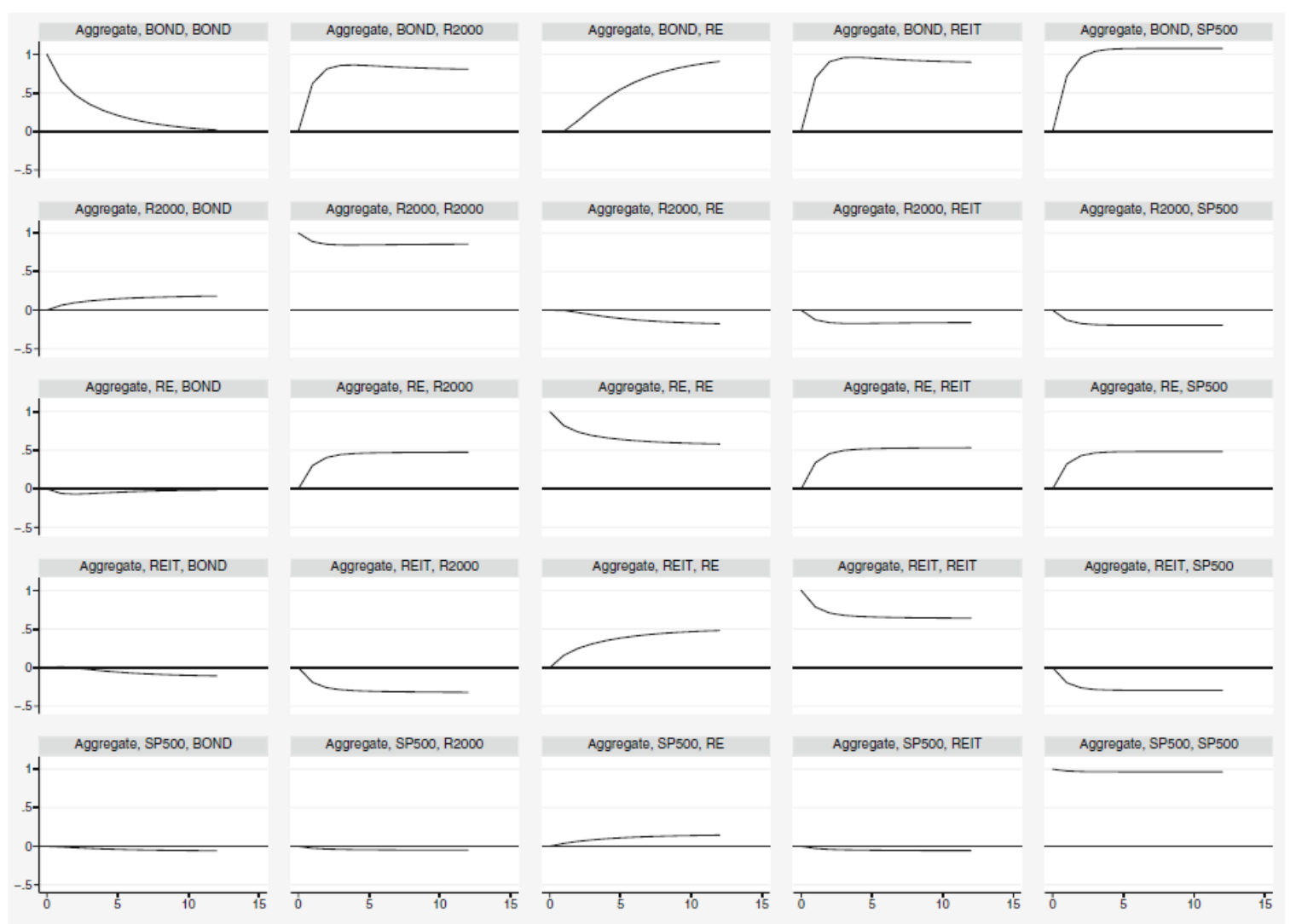

Fig. 2 Impulse Response Function (REIT Short Sample). Figure reports impulse response functions for the VECM (2) VECM includes REIT the NAREIT FTSE Equity REIT Index, RE the aggregate MIT/TBI index, the S\&P500 index, the Russell 2000 value index and the Barclay's BAA long term corporate bond index. Data are quarterly and cover the period Q2 1994 to Q4 2009. Impulse response functions are reported for every possible impulse and response combination in the VECM and are labeled as "Aggregate, Impulse variable, Response variable" 


\section{References}

Ackert, L., \& Smith, B. (1993). Stock price volatility, ordinary dividends and other cash flows to shareholders. Journal of Finance, 48, 1147-1160.

Anderson, R., Guirguis, H., Shilling, J. (2009). Price discovery and the dynamics among private real estate, REITs, stocks and bonds: A re-examination, Working paper, DePaul University.

Boudry, W. I. (2011). An examination of REIT dividend payout policy. Real Estate Economics, forthcoming.

Campbell, J. Y., \& Shiller, R. (1988). Stock prices, earnings, and expected dividends. Journal of Finance, 43, 661-676.

Campbell, J. Y., Lettau, M., Malkiel, B., \& Xu, Y. (2001). Have individual stocks become more volatile? An empirical exploration of idiosyncratic risk. Journal of Finance, 61, 1-43.

Chiang, K. (2009). Discovering REIT price discovery: A new data setting. Journal of Real Estate Finance and Economics, 39, 74-91.

Chiang, K., \& Lee, M. (2002). REITs in the decentralized investment industry. Journal of Property Investment and Finance, 20, 496-512.

Clayton, J., \& Mackinnon, G. (2003). The relative importance of stock, bond and real estate factors in explaining REIT returns. Journal of Real Estate Finance and Economics, 27, 39-60.

Engle, R. F., \& Granger, C. J. W. (1987). Co-integration and error correction: Representation, estimation and testing. Econometrica, 52, 251-276.

Fisher, J., Geltner, D., \& Pollakowski, H. (2007). A quarterly Transactions-Based Index (TBI) of Institutional Real Estate Investment Performance and Movements in Supply and Demand. Journal of Real Estate Finance and Economics, 36, 5-33.

Geltner, D., Miller, N., Clayton, J., Eichholtz, P. (2007). Commercial Real Estate Analysis and Investments. Southwestern Publishing.

Giliberto, M. (1990). Real estate investment trusts and real estate returns. Journal of Real Estate Research, 5, 259-263.

Glascock, J. L., Lu, C., \& So, R. W. (2000). Further Evidence on the Integration of REIT, Bond and Stock Returns. Journal of Real Estate Finance and Economics, 20, 177-194.

Hardin, W., \& Hill, M. (2008). REIT determinants: Excess dividends and capital markets. Real Estate Economics, 36, 349-369. 
Johansen, S. (1995). Likelihood-based inference in cointegrated vector autoregressive models. Oxford: Oxford University.

Kallberg, J. G., Liu, C. H., \& Srinivasan, A. (2003). Dividend pricing models and REITs. Real Estate Economics, 31, 435-450.

LeRoy, S., \& Porter, R. (1981). Stock price volatility: Tests based on implied variance bounds. Econometrica, 49, 97-113.

Ling, D., \& Naranjo, A. (2003). The dynamics of REIT capital flows and returns. Real Estate Economics, 31, 405-434.

Liu, C. H., \& Mei, J. (1992). The predictability of returns on equity REITs and their co-movement with other assets. Journal of Real Estate Finance and Economics, 5, 401-418.

Lütkepohl, H. (2005). New introduction to multiple time series analysis. Berlin: Springer.

Morawski, J., Rehkugler, H., \& Füss, R. (2008). The nature of listed real estate companies: Property or equity market? Financial Markets and Portfolio Management, 22, 101-126.

Mulhofer, T. (2011). Why do REIT returns poorly reflect property returns? Unrealizable appreciation gains due to trading constraints as the solution to the short-term disparity. Real Estate Economics, forthcoming.

Ooi, J., Wang, J., \& Webb, J. (2009). Idiosyncratic risk and REIT returns. Journal of Real Estate Finance and Economics, 38, 420-443.

Phillips, P. (1987). Time series regression with a unit root. Econometrica, 55, 277-302.

Phillips, P., \& Perron, P. (1988). Testing for unit root in time series regression. Biometrika, 75, 335-346. Seck, D. (1996). The substitutability of real estate assets. Real Estate Economics, 24, 75-96.

Seiler, M., Webb, J., \& Myer, F. C. N. (2001). Can real estate portfolios be rebalanced/diversified using equity REIT shares? Journal of Real Estate Portfolio Management, 1, 25-42.

Shiller, R. (1981). Do stock prices move too much to be justified by subsequent changes in dividends? The American Economic Review, 71, 421-435.

Shiller, R. (1989). Market volatility. Cambridge: MIT.

StataCorp. (2009). Stata 11 Time-Series Reference Manual. College Station, TX: Stata Press.

Tuluca, S., Myer, F. C. N., \& Webb, J. (2000). Dynamics of private and public real estate markets. Journal of Real Estate Finance and Economics, 21, 279-296.

West, K. (1988). Dividend innovations and stock price volatility. Econometrica, 56, 37-61.

Zeiring, B., Winograd, B., \& Mclntosh, W. (1997). The evolution of private and public markets: investing in the New Real Estate Capital Market. Parsippany: Prudential Real Estate Investors. 